\title{
Anabolic Androgenic Steroid Abuse and Cerebral Venous Thrombosis-A Case Report
}

\author{
Marlene Saraiva, João Pedro Marto, Ana Sofia Correia, and Miguel Viana Baptista \\ Neurology Department, Egas Moniz Hospital, Lisbon, Portugal
}

DOI: https://doi.org/10.17925/USN.2020.16.2.120

$\mathrm{T}$ here are a small number of published cases of cerebral venous thrombosis (CVT) associated with anabolic androgenic steroids (AASs). We present the case of a 27-year-old man who was admitted to the emergency room with a severe holocranial headache, nausea, vomiting, photophobia, and diplopia. He had no relevant past medical history, but he had been taking anabolic steroids for 1 year. The examination revealed papilledema and bilateral sixth nerve palsy. The computed tomography venography documented thrombosis of the left transverse and sigmoid sinuses. The patient was started on anticoagulant therapy with gradual improvement. The workup ruled out other causes of CVT. Despite the uncertainty about the exact mechanism by which AASs promote thrombosis, our case supports the conviction that high-dose and long-lasting AAS use should be considered a possible cause of CVT. Accordingly, it is of utmost importance to inquire about AAS use in case of suspected CVT.

\section{Keywords}

Anabolic androgenic steroids, cerebral venous thrombosis, steroid abuse

Disclosures: Marlene Saraiva, João Pedro Marto Ana Sofia Correia, and Miguel Viana Baptista have no financial or non-financial relationships or activities to declare in relation to this article.

Review Process: Double-blind peer review. Compliance with Ethics: Informed consent was received from the patient involved in this case study. Authorship: The named authors meet the International Committee of Medical Journal Editors (ICMJE) criteria for authorship of this manuscript, take responsibility for the integrity of the work as a whole, and have given final approval for the version to be published.

Access: This article is freely accessible at touchNEUROLOGY.com (c) Touch Medical Media 2020.

Received: May 8, 2020

Accepted: July 22, 2020

Published Online: December 23, 2020

Citation: US Neurology. 2020;16(2):120-2

Corresponding Author: Marlene Saraiva, Department of Neurology, Egas Moniz Hospital, Rua da Junqueira 126, 1349-019 Lisbon, Portugal. E: marlenesaraiva_@hotmail.com

Support: No funding was received in the publication of this article.
Cerebral venous thrombosis (CVT) is a rare condition. ${ }^{1-3}$ While thrombophilias, contraceptive pill, hormonal replacement therapy, and neoplasms are well-established predisposing factors, steroid use is a less-common possible risk factor, particularly with regard to anabolic androgenic steroids (AAS). ${ }^{1-4}$

We intend to describe what is known about AAS and present a case of CVT associated with AAS use in a young patient.

\section{Case presentation}

A 27-year-old man was admitted with a severe holocranial headache, nausea, vomiting, photophobia, and diplopia, which had begun 3 days before. He had no relevant past medical antecedent, no previous migrainous headache, nor any pertinent family history of hypercoagulability. However, he had been taking AASs for 1 year to increase muscle mass (intramuscular testosterone weekly, in addition to $400 \mathrm{mg}$ of oxymetholone and $300 \mathrm{mg}$ of nandrolone daily). On examination he had papilledema and bilateral sixth nerve palsy. Blood tests revealed thrombocytosis with 263,000 platelets $/ \mathrm{mm}^{3}$ without other alterations on hemogram like polycythemia. Computed tomography venography documented thrombosis of the left transverse and sigmoid sinuses (Figures 1 and 2). The workup ruled out other causes of CVT, such as hereditary thrombophilia, infection, or neoplasia. Autoimmune diseases and vasculitis syndromes were ruled out by appropriate investigations (e.g., screening for antinuclear antibodies [ANA], antiphospholipid antibodies [APLA], antineutrophil cytoplasmic antibodies [ANCA], cytoplasmic and perinuclear ANCA [CANCA and pANCA]). Vitamin B12, folic acid, and serum homocysteine levels were normal.

The patient was started on anticoagulant therapy with enoxaparin $1 \mathrm{mg} / \mathrm{kg}$ every 12 hours. A combination of analgesics and acetazolamide were introduced because of refractory headache. The follow-up magnetic resonance imaging, performed 6 months later, showed resolution of thrombosis.

\section{Discussion}

There are two main types of steroids, namely corticosteroids and AASs; the latter carrying a greater risk of thrombosis. Since their synthesis in 1935, AASs began to be widely consumed: firstly, by the elite athletes to improve their sports performance, and then by the general population, especially the younger, with the purpose of increasing muscle mass as well as a recreational drug, disregarding their harmful effects. ${ }^{5-6}$ In fact, AASs are synthetic derivatives of testosterone with a strong anabolic effect and only residual androgenic action. ${ }^{7}$ For that reason, they are used to treat several medical conditions, namely many forms of anemia, especially aplastic anemia; acute and chronic wounds; renal failure (in combination with recombinant human erythropoietin); protein-calorie malnutrition 


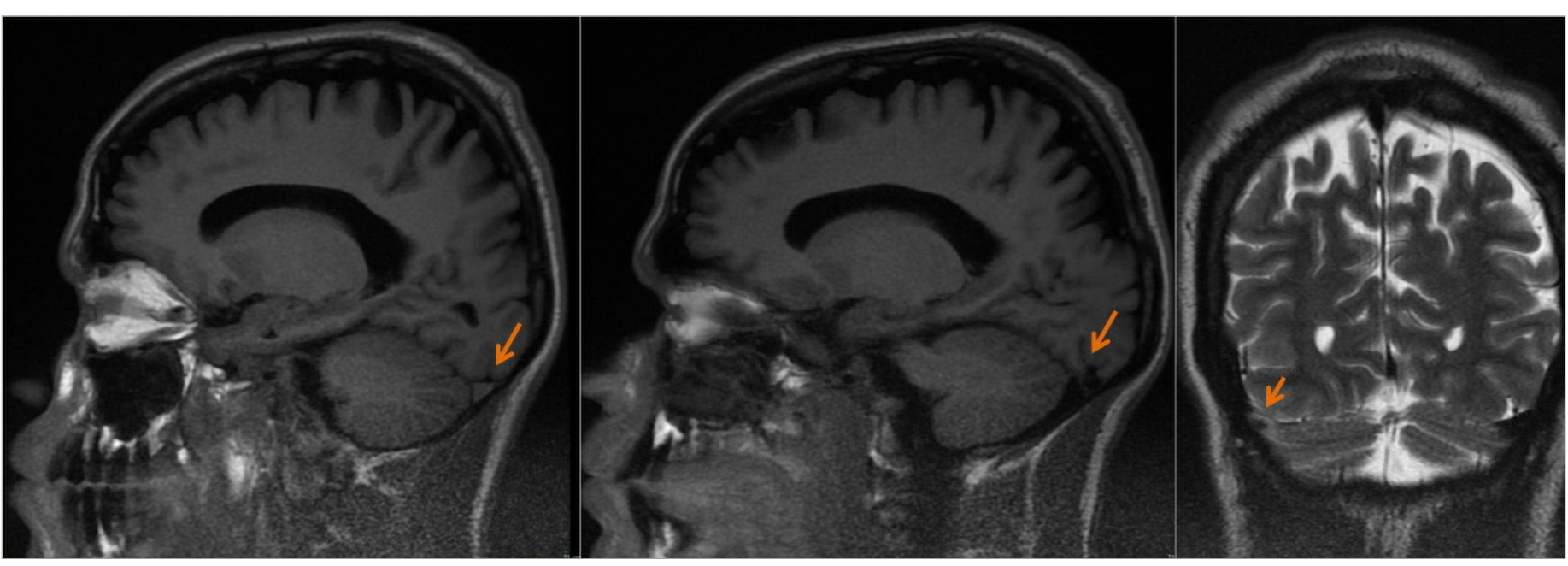

Figure 2: Magnetic resonance imaging-documented thrombosis of the left transverse and sigmoid sinuses

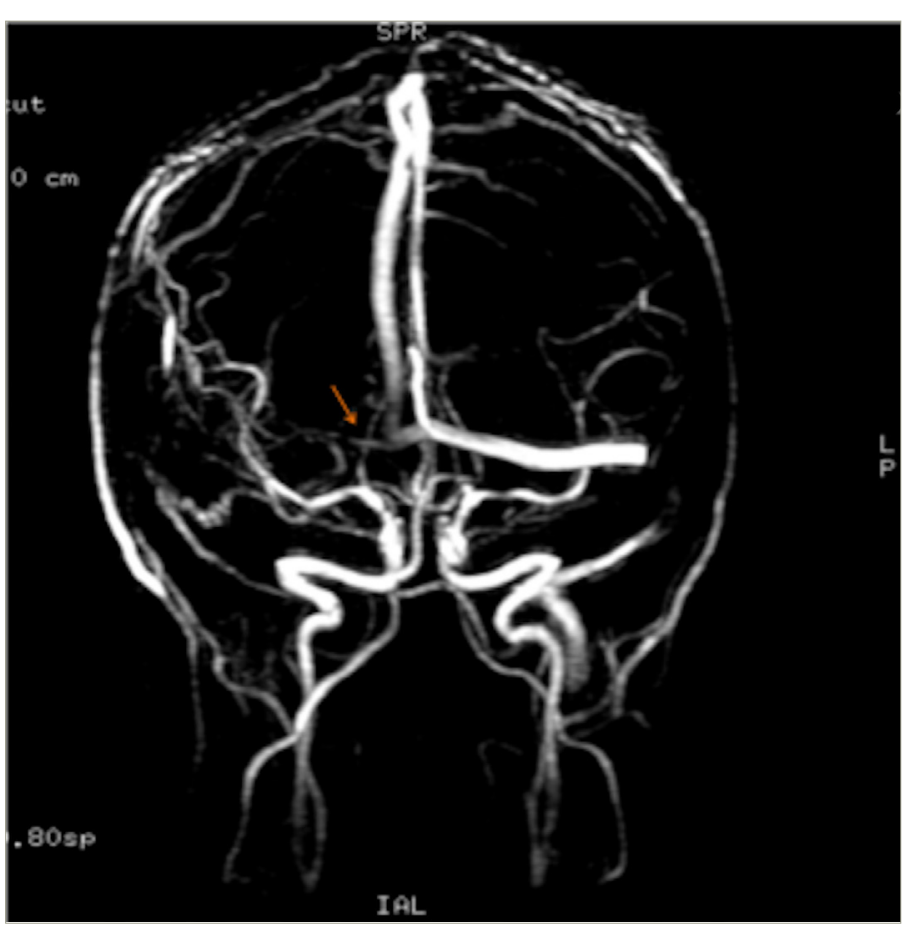

with associated weight loss, such as HIV-associated wasting syndrome; and cancer-associated cachexia. AASs approved by the US Food and Drug Administration, and their respective common dosages, are listed in Table 1.

Notwithstanding their benefits, the chronic use or abuse of AASs can cause several pathologic alterations, including hepatic, cardiovascular, reproductive, musculoskeletal, endocrine, renal, immunologic, and hematologic dysfunction, as well as psychological and psychiatric effects. Indeed, sudden cardiac death, suicide, and violent deaths have been reported to be more frequent than in the population in general in individuals with a history of long-term AAS use. . $^{-16}$
Table 1: Anabolic androgenic steroids approved by the US Food and Drug Administration

\begin{tabular}{|l|l|l|l|l|}
\hline & $\begin{array}{l}\text { Administration } \\
\text { form }\end{array}$ & Dosage & $\begin{array}{l}\text { Androgenic } \\
\text { effect }\end{array}$ & $\begin{array}{l}\text { Anabolic } \\
\text { effect }\end{array}$ \\
\hline $\begin{array}{l}\text { Nandrolone } \\
\text { decanoate }\end{array}$ & Intramuscular & $\begin{array}{l}50-100 \text { mg once } \\
\text { a week }\end{array}$ & Residual & Very high \\
\hline $\begin{array}{l}\text { Oxandrolone } \\
\left.\text { (Oxandrin }{ }^{\circledR}\right)\end{array}$ & Oral & $\begin{array}{l}2.5 \mathrm{mg} \text { two to } \\
\text { four times a day }\end{array}$ & Low & High \\
\hline $\begin{array}{l}\text { Stanozolol } \\
\text { (Winstrol) }\end{array}$ & Oral & $\begin{array}{l}\text { 2 mg three times } \\
\text { a day }\end{array}$ & Medium & Medium \\
\hline $\begin{array}{l}\text { Oxymetholone } \\
\text { (Anadrol }{ }^{\circledR} \text {-50) }\end{array}$ & Oral & $\begin{array}{l}\text { 1-5 mg/kg of } \\
\text { body weight per } \\
\text { day }\end{array}$ & High & High \\
\hline
\end{tabular}

Table 2: Published anabolic androgenic steroid-associated cerebral venous thrombosis cases

\begin{tabular}{|l|l|l|l|l|}
\hline Publication & $\begin{array}{l}\text { Gender/ } \\
\text { age }\end{array}$ & $\begin{array}{l}\text { Anabolic androgenic } \\
\text { Steroid }\end{array}$ & Use duration & Outcome \\
\hline $\begin{array}{l}\text { Jaillard et al. } \\
1994^{19}\end{array}$ & M, 31 & Not specified & Not specified & Favorable \\
\hline $\begin{array}{l}\text { Chu et al. } \\
2001^{17}\end{array}$ & F, 40 & Oxymetholone & 2 years & Favorable \\
\hline $\begin{array}{l}\text { Sahraian et al. } \\
2004^{20}\end{array}$ & M, 22 & Nandrolone & 5 months & Favorable \\
\hline $\begin{array}{l}\text { Sveinsson et al. } \\
2013^{22}\end{array}$ & M, 21 & Methandrostenolone & 4 months & Favorable \\
\hline
\end{tabular}

From the neurological point of view, some CVT cases have been reported in the last decade among AAS consumers, and there are probably many non-diagnosed cases due to the illegality of its use. AAS-associated CVT cases published until now are listed in Table 2, highlighting the type of AAS consumed, duration of use, and outcome of CVT. ${ }^{17-22}$ The exact mechanism by which AASs cause CVT is unknown; however, the existing evidence suggests that they promote fluctuations on the hemostatic system from an antithrombotic to a prothrombotic state. 
Additionally, in vitro experiences have shown that AASs can favor platelet agreggation. ${ }^{1-3,19}$

Despite the small number of published cases and the uncertainty about the exact mechanism by which AASs promote thrombosis, the fact that the patient had no medical relevant antecedents or risk factors, associated with the complete recovery after therapy, supports the conviction that high-dose and long-lasting AAS use should be considered a possible cause of CVT. Accordingly, it is very important to inquire about AAS use in cases of suspected CVT. $\square$
1. Coutinho JM. Cerebral venous thrombosis. J Thromb Haemost. 2015;13 Suppl. 1:S238-44.

2. Ferro $\mathrm{JM}$, Canhão $P$. Cerebral venous sinus thrombosis: update on diagnosis and management. Curr Cardiol Rep. 2014;16:523

3. Zuurbier SM, Coutinho JM. Cerebral venous thrombosis. Adv Exp Med Biol. 2017;906:183-93.

4. Saadatnia M, Fatehi F, Basiri K, et al. Cerebral venous sinus thrombosis risk factors. Int I Stroke. 2009;4:111-23.

5. Cooper I, Reeve N, Doherty W. Delayed diagnosis of a cerebrovascular accident associated with anabolic steroid use. BMJ Case Rep. 2011;2011:bcr0220113857.

6. Lippi G, Banfi G. Doping and thrombosis in sports. Semin Thromb Hemost. 2011;37:918-28.

7. Shahidi NT. A review of the chemistry, biological action, and clinical applications of anabolic-androgenic steroids. Clin The 2011;23:1355-90.

8. Ferenchick G, Schwartz D, Ball M, Schwartz K. Androgenic-anabolic steroid abuse and platelet aggregation: a pilot study in weight lifters. Am I Med SCi. 1992:303:78-82.

9. Busardò P, Frati P, Di Sanzo M, et al. The impact of nandrolone decanoate on the central nervous system. Curr Neuropharmaco. 2015;13:122-31.
10. Cheng J, Hu W, Toung TJ, et al. Age-dependent effects of testosterone in experimental stroke. I Cereb Blood Flow Metab. 2009;29:486-94.

11. Ferenchick GS. Anabolic androgenic steroid abuse and thrombosis: is there a connection? Med Hypotheses. 1991;35:27-31

12. Low MSY, Vilcassim S, Fedele P, Grigoriadis G. Anabolic androgenic steroids, an easily forgotten cause of polycythaemia and cerebra infarction. Intern Med J. 2016;46:497-9.

13. Nieschlag E, Vorona E. Doping with anabolic androgenic steroids (AAS): adverse effects on non-reproductive organs and functions. Rev Endocr Metab Disord 2015:16:199-211.

14. Pomara C. et al. Neurotoxicity by synthetic androgen steroids: oxidative stress, apoptosis, and neuropathology: a review. Curr Neuropharmacol. 2015;13:132-45.

15. Santamarina RD, Besocke AG, Romano LM, et al. Ischemic stroke related to anabolic abuse. Clin Neuropharmaco. 2018:31:80-5.

16. Youssef MYZ, Alqallaf A, Abdella N. Anabolic androgenic steroid-induced cardiomyopathy, stroke and peripheral vascular disease. BMJ Case Rep. 2011;2011:bcr1220103650.

17. Chu K, Kang DW, Kim DE, Roh JK. Cerebral venous thrombosis associated with tentorial subdural hematoma during oxymetholone therapy. J Neurol Sci. 2001;15;185:27-30.

18. García-Esperón C, Hervás-García JV Jiménez-González M, et al. Ingestion of anabolic steroids and ischaemic stroke. A clinical case report and review of the literature. Rev Neurol. 2013;56:327-31

19. Jaillard AS, Hommel M, Mallaret M. Venous sinus thrombosis associated with androgens in a healthy young man. Stroke. 1994;25:212-3.

20. Sahraian M, Mottamedi M, Azimi AR, Moghimi B. Androgen-induced cerebral venous sinus thrombosis in a young bodybuilder: case report. BMC Neurol. 2004;4:22.

21. Shimada $Y$, Yoritaka A, Tanaka $Y$, et al. Cerebral infarction in a young man using high-dose anabolic steroids. I Stroke Cerebrovasc Dis. 2012;21:906.e9-11.

22. Sveinsson O, Herrman L. Cortical venous thrombosis following exogenous androgen use for bodybuilding. BMJ Case Rep. 2013;2013:bcr2012008638

23. Khwaja GA, Srivastava A, Deshmukh A, Chaudhry N. Anabolic steroid abuse in gym enthusiasts - an under-recognized cause of cerebral venous thrombosis. MAMC J Med SCi. 2018;4:38-40 